\title{
Article
}

\section{Hybrid Sol-Gel Coatings Doped with Non-Toxic Corrosion Inhibitors for Corrosion Protection on AZ61 Magnesium Alloy}

\author{
Luis Rodríguez-Alonso ${ }^{1}$, Jesús López-Sánchez ${ }^{2,3}{ }^{\circledR}$, Aida Serrano ${ }^{4}\left(\mathbb{D}\right.$, Oscar Rodríguez de la Fuente ${ }^{1}$, \\ Juan Carlos Galván ${ }^{5}\left[\right.$ and Noemí Carmona ${ }^{1, *}$
}

1 Departamento de Física de Materiales, Facultad de Ciencias Físicas, Universidad Complutense de Madrid, Plaza Ciencias sn, 28040 Madrid, Spain; luisro03@ucm.es (L.R.-A.); osrodrig@ucm.es (O.R.d.l.F.)

2 SpLine, Spanish CRG BM 25 Beamline, ESRF-The European Synchrotron, 71 Av. Des Martys, 38000 Grenoble, France; jesus.lopez@ucm.es

3 Instituto de Ciencia de Materiales de Madrid (ICMM-CSIC), C/Sor Juana Inés de la Cruz, 3, 28049 Madrid, Spain

4 Instituto de Cerámica y Vidrio (ICV-CSIC), C/Kelsen 5, Campus de Cantoblanco, 28049 Madrid, Spain; aida.serrano@icv.csic.es

5 Centro Nacional de Investigaciones Metalúrgicas (CENIM-CSIC), Avda. Gregorio del Amo 8, 28040 Madrid, Spain; jcgalvan@cenim.csic.es

* Correspondence: ncarmona@ucm.es

check for

updates

Citation: Rodríguez-Alonso, L.

López-Sánchez, J.; Serrano, A.; Rodríguez de la Fuente, O.; Galván, J.C.; Carmona, N. Hybrid Sol-Gel Coatings Doped with Non-Toxic Corrosion Inhibitors for Corrosion Protection on AZ61 Magnesium Alloy. Gels 2022, 8, 34. https:// doi.org/10.3390/gels8010034

Academic Editor: Andrei Jitianu

Received: 30 November 2021

Accepted: 1 January 2022

Published: 5 January 2022

Publisher's Note: MDPI stays neutral with regard to jurisdictional claims in published maps and institutional affiliations.

Copyright: (C) 2022 by the authors. Licensee MDPI, Basel, Switzerland. This article is an open access article distributed under the terms and conditions of the Creative Commons Attribution (CC BY) license (https:// creativecommons.org/licenses/by/ $4.0 /)$.

\begin{abstract}
Physiological human fluid is a natural corrosive environment and can lead to serious corrosion and mechanical damages to light $\mathrm{Mg}-\mathrm{Al}$ alloys used in prosthetics for biomedical applications. In this work, organic-inorganic hybrid coatings doped with various environmentally friendly and non-toxic corrosion inhibitors have been prepared by the sol-gel process for the corrosion protection of AZ61 magnesium alloys. Effectiveness has been evaluated by $\mathrm{pH}$ measurements, optical microscopy, and SEM during a standard corrosion test in a Hanks' Balanced Salt Solution. The results showed that the addition of an inhibitor to the sol-gel coating can improve significantly the corrosion performance, being an excellent barrier for the L-cysteine-doped hybrid sol-gel films. The incorporation of $\mathrm{TiO}_{2}$ nanoparticles, 2-Aminopyridine and quinine organic molecules slowed down the corrosion rate of the $\mathrm{Mg}-\mathrm{Al}$ alloy. Graphene oxide seemed to have the same response to corrosion as the hybrid sol-gel coating without inhibitors.
\end{abstract}

Keywords: sol-gel; corrosion inhibitors; L-cysteine; Hanks' solution; AZ61 magnesium alloy

\section{Introduction}

The search for new metal alloys to be used in biomedicine has developed greatly in recent years. Among the properties, these new materials must stand out, i.e., good mechanical and elastic resistance, or at least similar to those of materials to be replaced (e.g., bone), good resistance to corrosion, and sufficiently high biocompatibility to avoid rejection $[1,2]$.

The most frequently used alloys today are Ti-based alloys [3,4] The widespread use of titanium and its alloys as a biomaterial in the manufacture of implants is due to the fact that they meet the requirements of biocompatibility, osseointegration, mechanical properties, corrosion resistance, processability, and availability. The high level of osseointegration is because when they are implanted in hard tissue, the bone is able to grow in direct contact with the implant, without an appreciable soft tissue capsule around it. Studies have also been carried out on new alloys, such as $\mathrm{Mg}-\mathrm{Al}$ alloy. This material is abundant in the Earth's crust, and the raw material has a reasonable cost. However, its processing requires certain precautions that make the manufacture of the alloy more expensive, so that the final cost is halfway between those of stainless steel and titanium alloys [5].

The use of magnesium in medical applications has been envisioned since the middle of the last century. However, its application has recently undergone an enormous increase, 
mainly due to its unique properties, which, together with its low weight, make it a suitable material for use in the field of bone implants [6]. One of the characteristics of this material is that its mechanical properties are similar to those of the bone, which is not the case with other materials used in orthopedic applications, such as titanium and stainless steel. This advantage allows better natural bone recovery processes. Thus, magnesium is a biocompatible and non-toxic material, allowing the development of bio-absorbable implants, which can be regulated in their time of permanence in the body to fulfill a certain function of recovery of a tissue and later degrade naturally $[7,8]$. The disadvantage of magnesium-containing alloys is their high reactivity. Therefore, it is necessary to apply some type of treatment or coating to improve their corrosion resistance [9].

Several techniques have been employed to reduce the corrosion rate of reactive alloys such as $\mathrm{Mg}$, for example laser shock processing [10], layer-by-layer deposition [11], electrospinning [12], or the sol-gel method. Specifically, among the possible coatings that can be used to protect $\mathrm{Mg}$-based alloys such as $\mathrm{Mg}-\mathrm{Al}$ alloys from degradation, the sol-gel process stands out as a very versatile, environmentally friendly and economical method of synthesis that has undergone significant development in recent years. Additionally, by this procedure, it is possible to synthesize bioactive materials only by adding functional groups such as $\mathrm{Si}-\mathrm{OH}, \mathrm{Ti}-\mathrm{OH}$, and $\mathrm{Zr}-\mathrm{OH}$ as precursors [13]. The sol-gel process is a very well-known synthetic route consisting in three fundamental stages, i.e., hydrolysis, polycondensation, and thermal densification. Starting from a colloidal suspension of very small particles in a liquid, it develops to a gel with a two-phase solid-liquid structure. The precursors used in the sol-gel process can be organic or inorganic. Among the numerous advantages of this technique, the following stand out: the high purity of the products is obtained due to the high control in the composition of the precursor materials; there is no need of a pretreatment to cover the metal surface; the synthesis can be carried out at room temperature and at atmospheric pressure; the process has low toxicity and is economical; coatings present good chemical resistance, constituting a powerful inhibitor of the corrosion in metals and alloys. Moreover, the nanoporosity of sol-gel coatings allows them to host other molecules that can preserve their properties and thus develop new potential applications, for example, as active corrosion protection methods [14,15].

Several corrosion inhibitors have been studied to improve the corrosion resistance of $\mathrm{Mg}-\mathrm{Al}$ alloys. The first ones studied are insoluble salts (e.g., $\mathrm{Ce}^{3+}[16], \mathrm{La}^{3+}[17]$, or $\mathrm{Zr}^{3+}$ ions [18]), then organic molecules and their derivatives that are less toxic and have better biodegradability. Most of the first organic inhibitors are weak acids, and some of the ones used lately are molecules containing various heteroatoms, such as aminoacids $[19,20]$. The use of polymers such as polyaniline or polypyrrole as conducting coatings has been also tested. Here, the mechanism for protection is not due to a barrier effect, but instead, it is believed that a passive oxide film is formed on the metal surface through an anodization process [21], giving the resulting metal/coating system self-healing properties and active corrosion protection [22-24]. Several types of nanoparticles (NPs) have been also tested $[25,26] . \mathrm{TiO}_{2} \mathrm{NPs}$ have shown to improve anticorrosion and antibacterial properties [27]. Graphene and its oxide nanosheets have been also used in sol-gel coatings due to their specific surface areas and impermeability for ions, water, and oxygen. However, they do not provide an active protection to the substrate $[28,29]$.

The aim of this work is to evaluate the corrosion protection of several hybrid sol-gel coatings doped with various environmentally friendly and non-toxic corrosion inhibitors deposited on an AZ61 Mg-Al alloy, in order to improve its low resistance to corrosion. Corrosion inhibitors such as L-cystine, dimethyl glyoxine, quinine, 2-Aminopyridine, graphene sheets, and $\mathrm{TiO}_{2} \mathrm{NPs}$ have been tested. The in vitro biodegradation and corrosion protection behaviors of the resulting hybrid sol-gel coatings have been evaluated by an immersion test in a Hanks' Balanced Salt Solution (HBSS) simulating the body fluid. 


\section{Experimental}

\subsection{Synthesis of the Coatings by the Sol-Gel Method}

The magnesium-aluminium (Mg-Al) alloy, commercially known as AZ61, was used as the substrate for the sol-gel coatings. It was composed of $6 \%$ by mass $\mathrm{Al}, 0.7 \%$ by mass $\mathrm{Zn}, 0.3 \%$ by mass $\mathrm{Mn}$, and the rest up to $100 \%$ by mass $\mathrm{Mg}$.

Tetraethyl orthosilicate (TEOS) and 3-(Trimethoxysilyl)propyl methacrylate (MEMO) were used as the precursors of sol-gel coatings (molar ratio, 1:1). Absolute ethanol $\left(\mathrm{CH}_{3} \mathrm{CH}_{2} \mathrm{OH}\right.$; Sigma-Aldrich) was employed as a solvent. Distilled water was added to promote the hydrolysis, and nitric acid was added as a catalyst $\left(\mathrm{HNO}_{3} ; 70 \%\right.$; Sigma-Aldrich, $)$. The molar concentrations of alkoxides, ethanol, and $\mathrm{HNO}_{3}$ were 1:4:0.05, respectively.

Prior to the hydrolysis of the sol, six different environmentally friendly substances were used as corrosion inhibitors, i.e., L-cysteine, dimethyl glyoxime, quinine, 2-Aminopyridine, graphene sheets [30], and $\mathrm{TiO}_{2} \mathrm{NPs}$, at a $0.02 \%$ weight/volume ratio (see Figure 1 ).

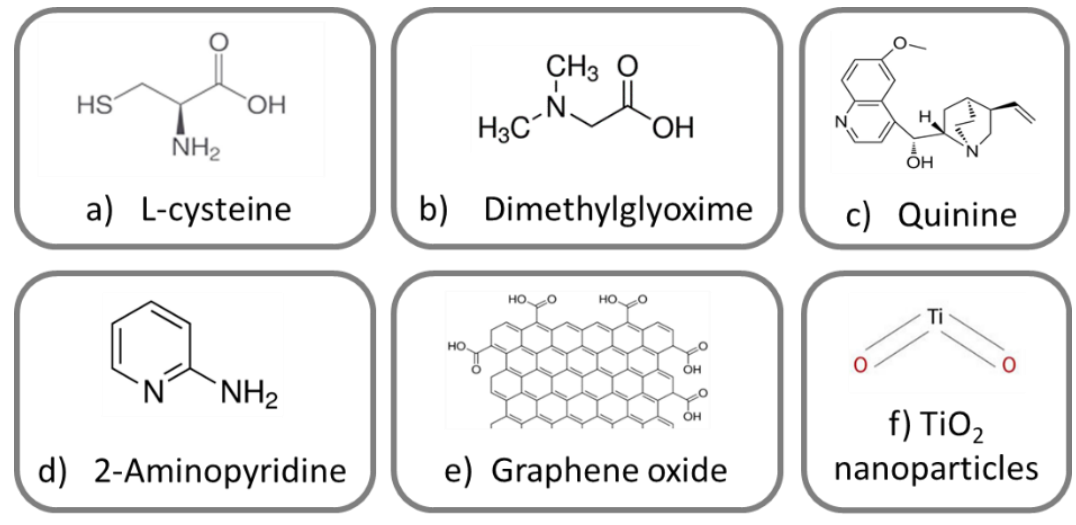

Figure 1. Corrosion inhibitors added into the sol-gel coatings: (a) L-cysteine; (b) dimetyl glyoxime; (c) quinine; (d) 2-Aminopyridine; (e) graphene oxide sheet; and (f) $\mathrm{TiO}_{2}$ nanoparticles.

They were chosen due to their properties as biocompatible molecules, complexing agents, or environmentally friendly NPs. Specifically, molecules with functional groups of the type amine, carbonyl, alcoholic groups, or conjugated bonds were selected, because they are more effective corrosion inhibitors [31].

Once the sol-gel coatings were prepared with the inhibitors, they were applied to AZ61 sheets with a $30 \mathrm{~mm} \times 30 \mathrm{~mm} \times 3 \mathrm{~mm}$ size by dip-coating. The withdrawal speed was $5 \mathrm{~mm} \cdot \mathrm{s}^{-1}$. A final thermal treatment was performed at $60^{\circ} \mathrm{C}$ for 3 days to complete the densification of the resulting coatings.

To evaluate the effectiveness of the coatings doped with several molecules after their application to the Mg alloy, a corrosion test with an HBSS was used. This is an aqueous solution widely used in in vivo tests that simulates physiological saline media. The samples were immersed for 14 days into the solution according to Standard ASTM G31 [32,33], and the $\mathrm{pH}$ was monitored every $24 \mathrm{~h}$. A Crison $\mathrm{pH} 25+$ digital laboratory portable $\mathrm{pH}-\mathrm{meter}$ was used for the data recording. After the 14-day test, the samples were removed from the solution and washed with distilled water 3 times. Then, they were left to be dried in the air and stored in a desiccator to prevent the corrosion of the surfaces.

\subsection{Samples Characterization Techniques}

The macroscopic information of the coatings surfaces on the $\mathrm{Mg}-\mathrm{Al}$ alloy before and after the degradation test was obtained by optical microscopy in the reflection mode with an Olympus BX60M optical microscope.

The surface characterization and semi-quantitative chemical composition analyses of the corroded surfaces and small deposits that remained adhered to the surface of the samples were carried out by SEM with an electronic microscope model JEOL JSM 6335F operating at an acceleration voltage of $20 \mathrm{kV}$. An energy-dispersive X-ray detector was 
employed for the elemental analysis of the surfaces. All samples were previously coated with $5 \mathrm{~nm}$ of $\mathrm{Au}$ to avoid charging effects.

\section{Results and Discussion}

\subsection{Samples Preparation}

Sol-gel coatings were prepared by mixing TEOS and MEMO at a molar ratio of 1:1. Absolute ethanol was added as a solvent in a solution with the selected corrosion inhibitor, and nitric acid was added as a catalyst. Stoichiometric quantities of water were added to perform the complete hydrolysis and polycondensation. The obtained sol was magnetically stirred for $24 \mathrm{~h}$, and the final $\mathrm{pH}$ was measured. All sols had an acid $\mathrm{pH}$ around 1-3, except the ones with quinine and 2-aminopyridine at $\mathrm{pH}$ values around 8-9.

The obtained sols were finally applied by dip-coating as explained in the experimental section, and a densification treatment was performed before the characterization of the samples. The coating thickness was obtained from the interference of transmittance spectra in the ultraviolet-visible and near-infrared regions according to [34]. All coatings resulted in thickness values below $100 \pm 30 \mathrm{~nm}$, except for the sample A-SG-DMG with a thickness value of $592 \pm 99 \mathrm{~nm}$. The descriptions of all the prepared samples are presented in Table 1.

Table 1. Descriptions of the prepared samples.

\begin{tabular}{cccc}
\hline Sample Name & $\begin{array}{c}\text { Sol-Gel Coating at a } \\
\text { TEOS:MEMO Ratio of 1:1 }(\boldsymbol{v} / \boldsymbol{v})\end{array}$ & $\begin{array}{c}\text { Corrosion } \\
\text { Inhibitor Added }\end{array}$ & $\begin{array}{c}\text { Corrosion Test } \\
\text { Performed }\end{array}$ \\
\hline 0 & No & No & No \\
\hline A & No & No & Yes \\
\hline A-SG & Yes & No -cysteine & Yes \\
\hline A-SG-CIS & Yes & Dimethyl glyoxime & Yes \\
\hline A-SG-DMG & Yes & Quinine & Yes \\
\hline A-SG-QUI & Yes & 2-Aminopyridine & Yes \\
\hline A-SG-AMIN & Yes & Graphene oxide & Yes \\
\hline A-SG-GRA & Yes & TiO 2 nanoparticles & Yes \\
\hline A-SG-TI & Yes & &
\end{tabular}

\subsection{Weathering Test}

In order to explore the corrosion behavior of the coated surfaces, the samples were placed in closed containers containing approximately $150 \mathrm{~mL}$ of a commercial HBSS at room temperature for 14 days, as explained in the experimental section. The $\mathrm{pH}$ of each solution was measured every day. The $\mathrm{pH}$ of the Hanks' solution itself $(\mathrm{pH}=7.23)$ was measured at the beginning of each day's measurement as a reference. The results of the variation of these $\mathrm{pH}$ measurements for all samples are shown in Figure 2.

For all cases, the increases in $\mathrm{pH}$ for all solutions during the 14 days of test were measured, reaching the maximum value at day 14. The dynamic process of the corrosion depended on the inhibitor incorporated into the coating identifying the largest $\mathrm{pH}$ difference for the sample A-SG in the 14 days, while the lowest gradient was observed for sample A-SG-CIS. The rest of samples showed $\mathrm{pH}$ gradients in the 14 days very similar between each other and within the error of the measurement. 

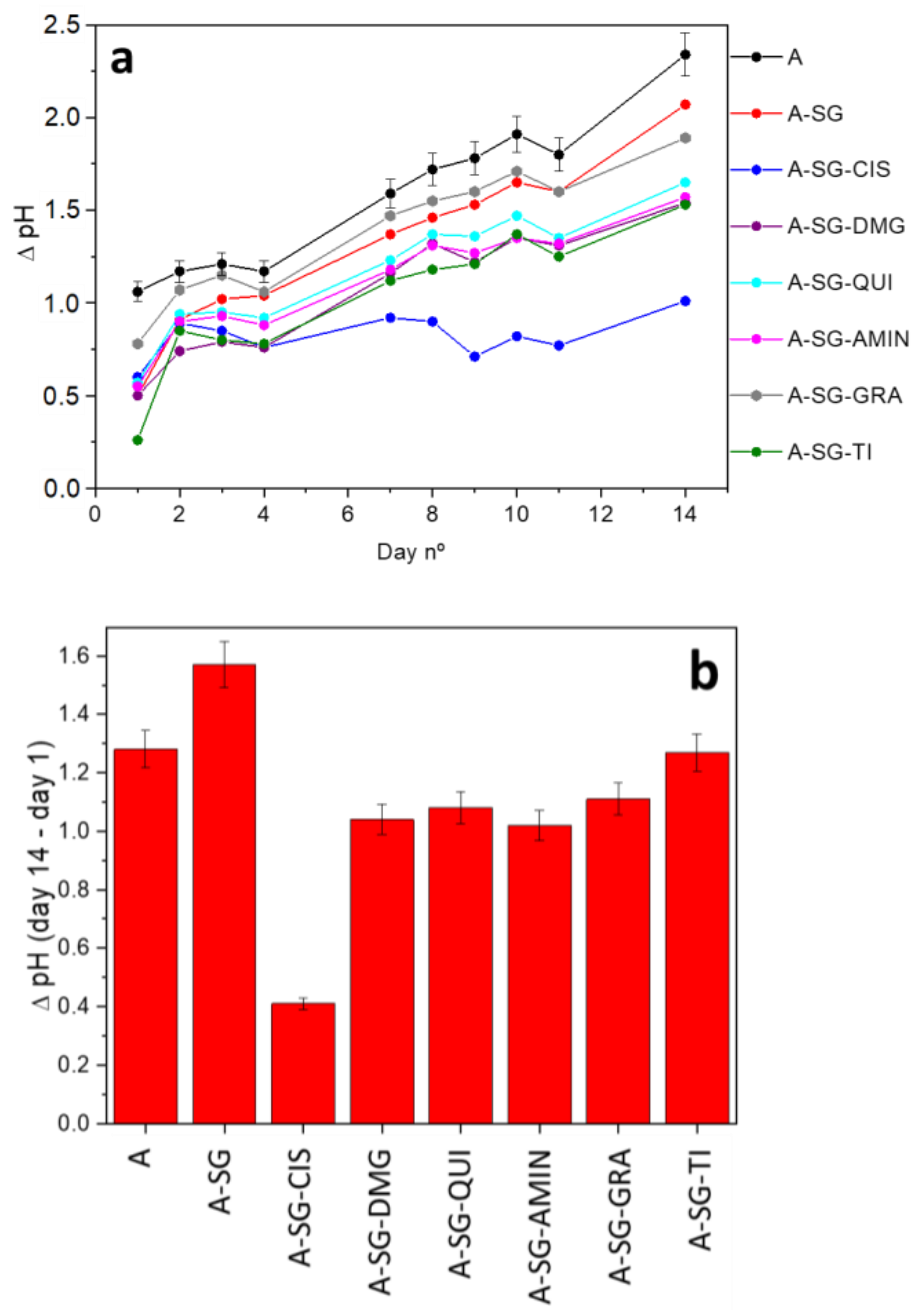

Figure 2. (a) Increase in $\mathrm{pH}$ of the solution versus the day of the test for samples A, A-SG, A-SG-GRA, A-SG-QUI, A-SG-AMIN, A-SG-DMG, A-SG-TI, and A-SG-CIS; (b) pH gradient measured for the 14 days of test in a Hanks' Balanced Salt Solution (HBSS).

The increases in the $\mathrm{pH}$ of the samples were due to the fact that the Hanks' solution acted as a biological fluid, which caused corrosion over the time. The corrosion mechanism of $\mathrm{Mg}$-based alloys is well-known, and the following reactions take place in the presence of water:

$$
\begin{gathered}
\text { Anodic reaction: } \mathrm{Mg}_{(\mathrm{s})} \rightarrow \mathrm{Mg}^{2+}(\mathrm{ac}) \\
\text { Cathodic reaction: } 2 \mathrm{H}_{2} \mathrm{O}+2 \mathrm{e}^{-} \rightarrow \mathrm{H}_{2(\mathrm{~g})}+2 \mathrm{OH}^{-} \text {(ac) }
\end{gathered}
$$

The obtained $\mathrm{OH}^{-}$ions were responsible of the $\mathrm{pH}$ increase of the Hanks' solution during the 14 days of test. In the first week, the $\mathrm{pH}$ values of all solutions increased considerably, and it was in the second week where three different behaviors were observed that the coatings were divided in three different groups:

(i) The solutions of the uncoated alloy (sample A), the sample coated with the hybrid sol-gel without corrosion inhibitors (sample A-SG), and the sol-gel coating with graphene oxide as an inhibitor (sample A-SG-GRA) showed increasing $\mathrm{pH}$ values throughout the test for 14 days. Thus, it indicated that both the uncoated alloy and the alloy coated with the blank sol-gel deteriorated throughout the test in the same way. This behavior is particularly interesting, because it indicated that a hybrid sol-gel coating without inhibitors was not effective as a protective layer against corrosion.

The increment of $\mathrm{pH}$ for the graphene oxide-doped sol-gel coating indicated that the barrier effect of the graphene sheets did not act enough, perhaps because the concen- 
tration of the inhibitor added was not the optimal one, and other concentrations should be researched.

(ii) Samples A-SG-QUI, A-SG-AMIN, A-SG-DMG, and A-SG-TI stabilize $\mathrm{pH}$ values after two days of the test, and then, the increment of $\mathrm{pH}$ increased very slowly. This is probably due to the fact that the coating was very thin and nanoporous, so it did not exert a barrier effect from the beginning but allowed some corrosion of the alloy that acted as a substrate until a point was reached, where the coating inhibitors acted and protected against corrosion. This happened from the 7th day until the end of the test.

(iii) Finally, the solution containing sample A-SG-CIS showed an increase in $\mathrm{pH}$ during the first two days, and from the third day onwards, its $\mathrm{pH}$ value stabilized or decreased progressively, which was more similar to the behavior of a self-repairing coating. The increase of $\mathrm{pH}$ for this sample was less than $0.75 \mathrm{pH}$ after the 14 days test.

Therefore, the corrosion behavior depended significantly on the inhibitor incorporated in the coating, and the effect was clearly reflected on the coating surfaces.

Figure 3 shows the photographs of the dried sample surfaces after the HBSS corrosion test. It can be seen how the corrosion affected the surface layer of the coating macroscopically and, in some cases, the deterioration reached the inner part of the alloy.

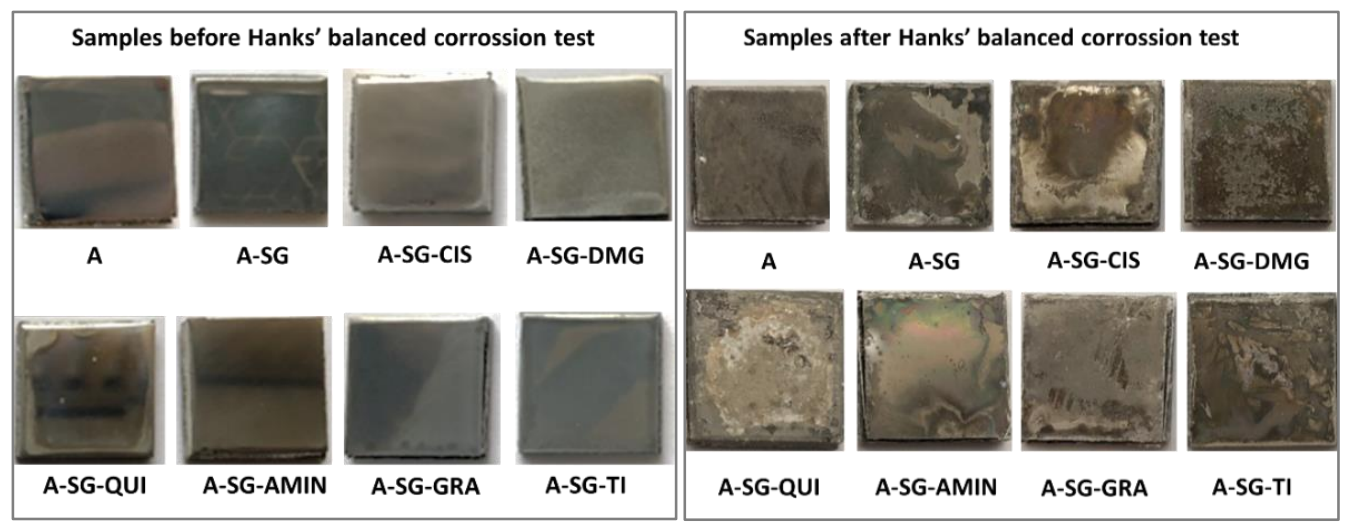

Figure 3. Representative macroscopic surfaces of the $\mathrm{Mg}-\mathrm{Al}$ alloys substrates before and after immersion in an HBSS for 14 days for samples A, A-SG, A-SG-CIS, A-SG-DMG, A-SG-QUI, A-SGAMIN, A-SG-GRA, and A-SG-TI. All square pieces had a size of $3 \mathrm{~mm} \times 3 \mathrm{~cm}$.

\subsection{Optical Microscopy Characterization}

Figure 4 shows the optical microscopy (OM) images of the surfaces of the samples. The AZ61 alloy used as a reference (as received) and not submitted to the HBSS corrosion test (sample 0, Figure 4a), showed a smooth polished surface with some streaks in random directions due to the polished effect.

Figure $4 \mathrm{~b}-\mathrm{i}$ shows the optical microscopy images of the samples tested in the HBSS. In general, all of them suffered some kind of deterioration after the test as identified by $\mathrm{pH}$ measurements. With the exception of sample A (Figure $4 \mathrm{~b}$ ), which was not coated, the rest maintained the coating with more or less cracks. Sample A lost its original luster and showed an uneven surface, chemically attacked with the presence of deposits. In turn, the sol-gel-coated sample without inhibitors (sample A-SG, Figure 4c) showed a moderate corrosion state with several cracks and pits.

In the same line, the sol-gel coated samples doped with corrosion inhibitors can be divided into two groups: (i) the first group of samples corresponding to samples A-SG-CIS, A-SG-DMG, and A-SG-TI with most of the surface in good conditions, except for the edges of the alloy that were more corroded and cracked (Figure 4d,e,i); and (ii) the second group of samples with a generalized corrosion on the whole surface and cracks of different sizes. Big cracks partially detached from the alloy appeared on samples A-SG-QUI and A-SGGRA (Figure 4f,h), and very thin small cracks adhered to the surface for the A-SG-AMIN coating were noted (Figure 4g). 


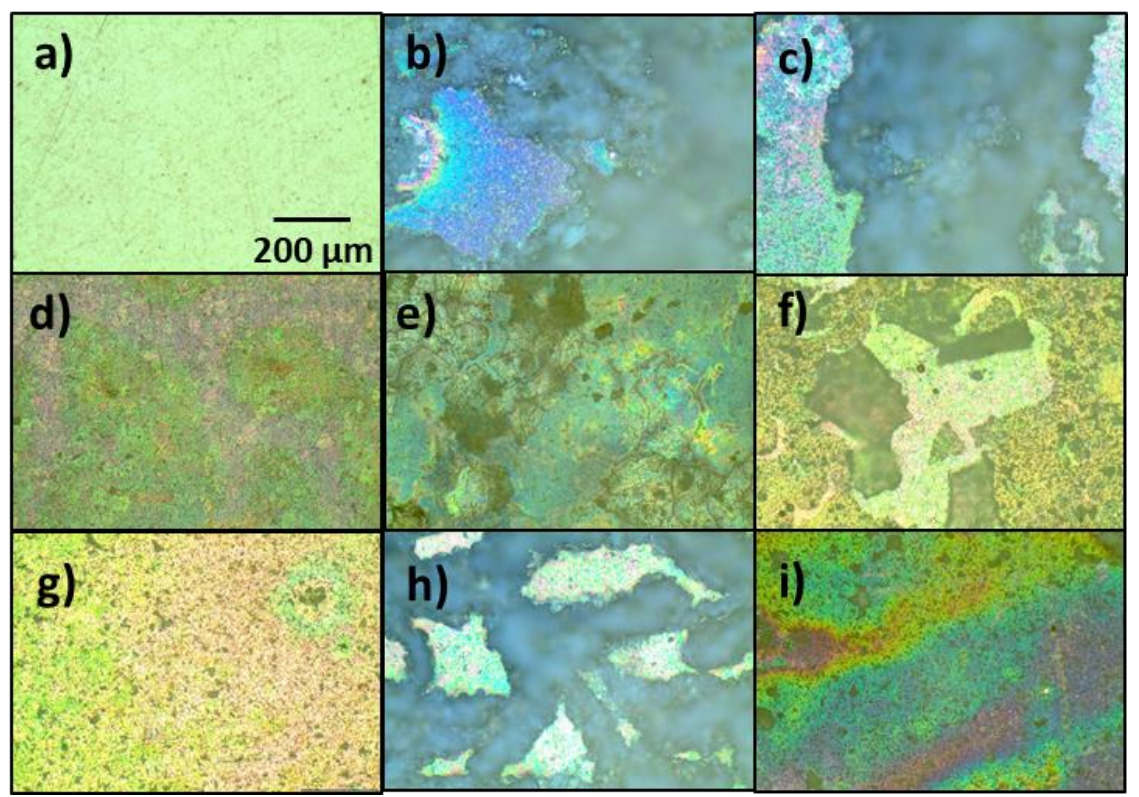

Figure 4. Optical microscopy images of the surfaces of the samples: (a) sample 0, uncorroded AZ61 alloy as received; (b) sample A, corroded AZ61 alloy after the Hank's solution corrosion test; (c) corroded sample A-SG; (d) corroded sample A-SG-CIS; (e) corroded sample A-SG-DMG; (f) corroded sample A-SG-QUI; (g) corroded sample A-SG-AMIN; (h) corroded sample A-SG-GRA; and (i) corroded sample A-SG-TI.

\subsection{SEM Characterization}

The surface morphologies of the samples were observed in detail by SEM in Figure 5, and EDX analyses were performed to verify the compositions of the compounds found, shown in Table 2.
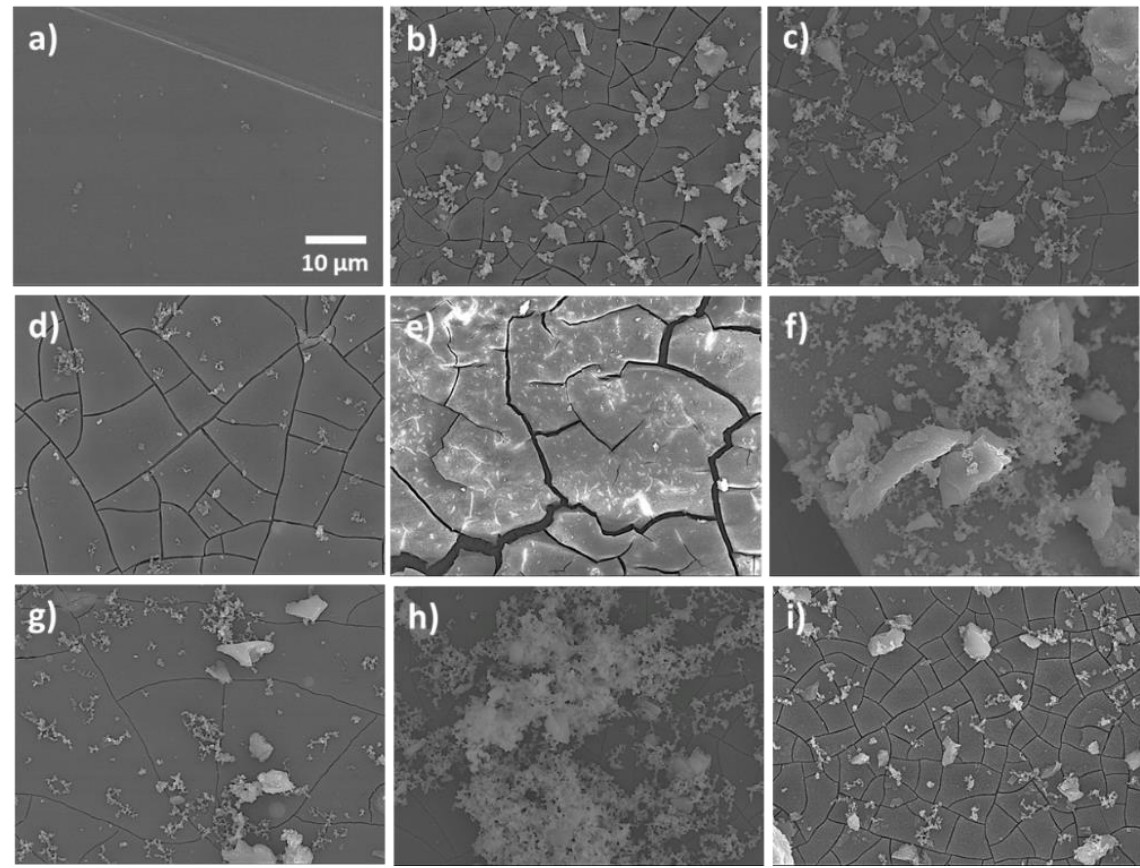

Figure 5. SEM images of the surfaces of the samples: (a) sample 0, uncorroded AZ61 alloy as received; (b) sample A, corroded AZ61 alloy after the HBSS corrosion test; (c) corroded sample A-SG; (d) corroded sample A-SG-CIS; (e) corroded sample A-SG-DMG; (f) corroded sample A-SG-QUI; (g) corroded sample A-SG-AMIN; (h) corroded sample A-SG-GRA; and (i) corroded sample A-SG-TI. 
Table 2. Chemical compositions of the surfaces of the prepared samples performed by EDX.

\begin{tabular}{|c|c|c|c|c|c|c|c|c|c|}
\hline \multirow{2}{*}{$\begin{array}{l}\text { Chemical } \\
\text { Composition } \\
\text { (wt \%) }\end{array}$} & \multicolumn{9}{|c|}{ Samples } \\
\hline & 0 & A & A-SG & A-SG-CIS & $\begin{array}{l}\text { A-SG- } \\
\text { DMG }\end{array}$ & $\begin{array}{l}\text { A-SG- } \\
\text { QUI }\end{array}$ & A-SG-AMIN & A-SG-GRA & A-SG-TI \\
\hline $\mathrm{Mg}$ & $91.6 \pm 0.7$ & $61.8 \pm 1.0$ & $51.6 \pm 1.4$ & $51.6 \pm 0.4$ & $3.8 \pm 0.1$ & $27.5 \pm 0.4$ & $62.9 \pm 0.8$ & $53.1 \pm 0.7$ & $50.6 \pm 1.0$ \\
\hline $\mathrm{Al}$ & $5.0 \pm 0.4$ & $4.7 \pm 0.4$ & $3.9 \pm 0.3$ & $5.8 \pm 0.1$ & $0.3 \pm 0.1$ & $2.3 \pm 0.1$ & $4.8 \pm 0.2$ & $3.5 \pm 0.1$ & $4.1 \pm 0.4$ \\
\hline $\mathrm{Si}$ & - & - & $0.5 \pm 0.2$ & $2.5 \pm 0.1$ & $22.1 \pm 0.4$ & $4.0 \pm 0.1$ & $0.2 \pm 0.1$ & $0.5 \pm 0.1$ & - \\
\hline $\mathrm{C}$ & - & - & $7.6 \pm 2.0$ & $5.1 \pm 0.6$ & $32.3 \pm 1.0$ & $19.8 \pm 1.0$ & $5.8 \pm 1.0$ & $4.7 \pm 0.9$ & - \\
\hline $\mathrm{O}$ & $3.4 \pm 0.6$ & $26.4 \pm 1.0$ & $28.7 \pm 1.2$ & $29.8 \pm 0.3$ & $40.7 \pm 0.8$ & $35.4 \pm 0.7$ & $21.3 \pm 0.5$ & $26.0 \pm 0.5$ & $29.9 \pm 1.2$ \\
\hline $\mathrm{Ca}$ & - & $3.2 \pm 0.2$ & $4.0 \pm 0.3$ & $1.7 \pm 0.1$ & $0.8 \pm 0.1$ & $5.3 \pm 0.1$ & $1.9 \pm 0.1$ & $4.4 \pm 0.1$ & $7.5 \pm 0.4$ \\
\hline $\mathrm{Cl}$ & - & - & - & - & - & - & $0.2 \pm 0.1$ & - & - \\
\hline $\mathrm{P}$ & - & $3.9 \pm 0.4$ & $3.7 \pm 0.4$ & $2.9 \pm 0.1$ & - & $3.4 \pm 0.1$ & $2.2 \pm 0.1$ & $4.4 \pm 0.1$ & $7.9 \pm 0.5$ \\
\hline $\mathrm{Nb}$ & - & - & - & - & - & $2.3 \pm 0.4$ & - & $2.8 \pm 0.4$ & - \\
\hline $\mathrm{Zn}$ & - & - & - & $0.6 \pm 0.1$ & - & - & $0.7 \pm 0.2$ & $0.6 \pm 0.2$ & - \\
\hline
\end{tabular}

Sample 0, corresponding to the AZ61 alloy as received, presented a smooth surface with some scratches, most likely due to surface polishing as observed by optical microscopy (Figure 5a). Small white granular deposits were also observed on the surface of the sample. The EDX analysis of the surface indicated a composition similar to the nominal composition of the alloy [35]. In our case, $\mathrm{Mg}$ had $91 \mathrm{wt} \%$, and $\mathrm{Al} \mathrm{had} 5 \mathrm{wt} \%$. There was also a residual $3 \%$ of the weight, which may be due to the oxidation of the alloy surface (Table 2). The local EDX analysis carried out on one of the white deposits on the surface showed that they were less soluble phosphorus salts and hydrated carbonates, most certainly coming from the HBSS.

The surface of sample A (Figure $5 b$ ) had a deteriorated appearance with white deposits and cracks over its entire surface. The analysis of its surface showed a lower Mg content $(61.8 \mathrm{wt} \%)$ compared to the unattacked alloy $(91.6 \mathrm{wt} \%)$. The O content increased from 3.4 to $26.4 \mathrm{wt} \%$, indicating a strong oxidation of the $\mathrm{Mg}$ in the alloy. The $\mathrm{Al}$ content remained more or less stable at around $5 \mathrm{wt} \%$ in both samples. This indicated that what reacted in the alloy was the $\mathrm{Mg}$. The presence of $\mathrm{Ca}$ and $\mathrm{P}$ in this sample is due to poorly soluble salts from the HBSS that were not removed after the cleaning process with distilled water and remained adhered to the sample surface (Table 2).

The SEM images of sample A-SG showed a cracked surface with numerous deposits on its surface (Figure 5c). The crack spacing appeared to be narrower in this sample than in the uncoated sample. The EDX analyses showed the presence of a small amount of Si $(0.5 \mathrm{wt} \%)$ and $\mathrm{C}(7.6 \mathrm{wt} \%)$, most likely due to the thin organic-inorganic hybrid coating layer that remained adhered to the surface of the sample (Table 2).

Sample A-SG-CIS showed a homogeneously cracked surface, with no detachment from the substrate alloy and some whitish deposits (Figure 5d). The EDX analyses indicated the presence of the sol-gel coating ( $2.5 \mathrm{wt} \% \mathrm{Si}, 5.1 \mathrm{wt} \% \mathrm{C}$, and $29.8 \mathrm{wt} \% \mathrm{O})$. The high amounts of oxygen and phosphorus indicated the formation of phosphates, oxides, and hydroxides of magnesium or calcium due to the corrosion process $(1.7 \mathrm{wt} \% \mathrm{Ca}$ and $2.9 \mathrm{wt}$ $\%$ P) (Table 2).

The surface of sample A-SG-DMG appeared cracked in SEM images, but the coating continued to be adhered to the surface. The area between the cracks was larger, and the cracks seemed to be deeper than in the case of the previous sample (Figure 5e). The EDX analysis of the surface showed higher amounts of $\mathrm{Si}(22.1 \mathrm{wt} \%)$ and $\mathrm{C}(32.3 \mathrm{wt} \%)$. The relative amounts of the alloy (the content of $\mathrm{Mg}: 3.8 \mathrm{wt} \%$; the content of $\mathrm{Al}: 0.3 \mathrm{wt} \%$ ) seemed to indicate that the coating was thicker than previous coated samples (Table 2).

Sample A-SG-QUI showed whitish deposits of insoluble salts of Hanks' solution and areas of the partially detached coating on its surface (Figure $5 \mathrm{f}$ and Table 2). From the EDX analysis, the presence of calcium phosphates was deduced ( $5.3 \mathrm{wt} \% \mathrm{Ca}$ and $3.4 \mathrm{wt} \% \mathrm{P}$ ), together with the sol-gel coating ( $4.0 \mathrm{wt} \% \mathrm{Si}, 19.8 \mathrm{wt} \% \mathrm{C}$, and $35.4 \mathrm{wt} \% \mathrm{O}$ ) (Table 2). 
Sample A-SG-AMIN (Figure 5g) showed a homogeneous surface with small cracks, less abundant than sample A. Some white deposits can also be appreciated (Figure $5 \mathrm{~g}$ and Table 2). The EDX analysis indicated a high proportion of the alloy (62.9 wt \% Mg and $4.8 \mathrm{wt} \% \mathrm{Al})$, so the surface would be less corroded but very oxidized $(21.3 \mathrm{wt} \% \mathrm{O})$. Small amounts of $\mathrm{Si}$ and $\mathrm{C}$ from the sol-gel coating were also visible, as well as deposits of calcium phosphate salts from the Hanks' solution.

The SEM images of sample A-SG-GRA showed uniform corrosion on the surface, with few cracks and abundant deposits of white salts (Figure 5h). The EDX analysis indicated the presence of $\mathrm{Si}, \mathrm{C}$, and $\mathrm{O}$ coming from the coating, traces of insoluble salts from the Hanks' solution ( $\mathrm{Ca}$ and $\mathrm{P})$, and $\mathrm{Mg}$ and $\mathrm{Al}$ together with small amounts of $\mathrm{Nb}(2.8 \mathrm{wt}$ $\%)$ and $\mathrm{Zn}(0.6 \mathrm{wt} \%)$ that came from the alloy composition (Table 2). These results are consistent with results from Gong et al. [36].

Sample A-SG-TI, including $\mathrm{TiO}_{2} \mathrm{NPs}$ in the overlying sol-gel coating as a corrosion inhibitor, showed a cracked surface with white deposits. The cracks spacing of this sample seemed to be like in the uncoated corroded alloy (Figure $5 i$ ). No Si or $C$ was observed in the EDX analysis, so the coating may have flaked off. The high amount of O $(29.9 \mathrm{wt} \%)$ may indicate a high oxidation of the $\mathrm{Mg}-\mathrm{Al}$ alloy, and $\mathrm{Ca}$ and $\mathrm{P}$ were also visible, indicating the presence of salt residues from the Hanks' solution. Ti was also not observed in the analysis, because the amount added in the coating was $0.02 \%$ weight/volume and the thickness of the coating was around $100 \mathrm{~nm}$, so the Ti content may be below the detection limit of the technique (Table 2).

From the results obtained here, in addition to the degradation of the AZ61 alloy during the Hanks' solution corrosion test, we confirmed that all coatings degraded to a greater or lesser extent. However, appreciable differences were found in the different coatings prepared.

The uncoated alloy immersed in the Hanks' solution for 14 days for the test suffered strong surface oxidation, suggested by the $\mathrm{pH}$ measurements. Fine cracks appeared, noticeable by both optical and scanning electron microscopies.

The use of coatings with corrosion inhibitors improved the anticorrosion properties, with properties depending on the corrosion inhibitors incorporated in the coating. The corrosion inhibitor that seemed to work best was L-cysteine (Figure 2). The $\mathrm{pH}$ of the Hanks' solution with the coated sample A-SG-CYS increased for the first two days, and then it maintained stable during the rest of 12 days. The total $\mathrm{pH}$ increased by only 0.75 . In fact, the optical microscopy and SEM images showed similar behaviors to those of the uncoated sample with less cracks and crystalline deposits on its surface.

Samples A-SG-DMG, A-SG-QUI, A-SG-AMIN, and A-SG-TI presented an increase of the $\mathrm{pH}$ during the Hanks' solution corrosion test (Figure 2), cracks, and white deposits on their surfaces (Figures 4 and 5).

Sample A-SG-GRA showed an increase of the $\mathrm{pH}$ of the Hanks' solution closer to the A-SG blank sample without corrosion inhibitors (Figure 2). Macroscopically, it showed partially detached cracks (Figure 4) and abundant white deposits on its surface (Figure 5). This behavior may be due to an inadequate proportion of the graphene nanosheets within the sol-gel coating. The EDX analysis also showed the presence of $\mathrm{Nb}$ and $\mathrm{Zn}$ ions, which were most likely the result of alloy degradation (Table 2). These minority components, due to their low solubility, appeared concentrated and deposited on the surface of $\mathrm{Mg}$ alloys [36].

The presence of the elements P and Ca in the EDX chemical analyses indicated the formation of insoluble calcium phosphate salts when the alloy was put in contact with Hanks' solution simulating the biological fluid (Table 2). Their presence was related to the formation of hydroxyapatite (bone component) [37]. Therefore, an $\mathrm{Mg}-\mathrm{Al}$ alloy with a coating that favored its growth formed more stable bonds and had better biocompatibility. The chemical and structural similarity of the alloy to be used as a biomaterial was greater in this case, creating optimal physicochemical conditions for the proliferation of bone cells, improving the physical, chemical, and biological activities of the implant. In our particular 
case, samples A-SG-QUI, A-SG-GRA, and A-SG-TI can have this characteristic, as they had high weights \% of $\mathrm{P}$ and $\mathrm{Ca}$ on their surfaces (Table 2 ).

NPs added to the sol-gel hybrid coating did not perform a better corrosion effect than the ones containing molecules. OM(Optical microscopy) and SEM images appear more deteriorated than those samples that include molecules as corrosion inhibitors. For this reason, for corrosion protection in biological fluids we would say that molecules work better as protection. Among the molecules tested, sample A-SG-CIS shows the protection desirable for the AZ61 alloy in implant applications.

\section{Conclusions}

Mg alloys are good options to be used as biocompatible prostheses for humans, when these alloys are surrounded by biological fluid undergoing a certain degree of corrosion over time. In this work, we have prepared several hybrid sol-gel coatings doped with potential corrosion inhibitors as alternatives to improve the corrosion resistance of the AZ61 magnesium alloy.

The effectiveness of the hybrid sol-gel coatings with and without corrosion inhibitors has been evaluated by subjecting coated AZ61 magnesium alloy samples to a Hanks' solution corrosion test by simulating the biological fluid during 14 days.

The results of this research showed that these sol-gel coatings were suitable to improve long-term performance of the AZ61 magnesium alloy. Coatings adhesion was good even without any kind of pre-treatment. After the Hanks' solution corrosion test, sol-gel coatings were still adhered to the alloy surface. The $\mathrm{pH}$ of the solution of the non-coated alloy increased during the 14 days of the corrosion test, and a decrease of the $\mathrm{pH}$ was noticed for the coated sample.

After the Hanks solution corrosion test, the hybrid sol-gel coating doped with Lcysteine stood out from the others, keeping the $\mathrm{pH}$ of the solution constant after two days and thus indicating that a stabilization of the corrosion rate might take place. Other molecules such as dimethyl glyoxime, quinine, 2-Aminopyridine, or $\mathrm{TiO}_{2} \mathrm{NPs}$ diminished the corrosion rate of the sol-gel coating, when they were introduced as corrosion inhibitors but underwent a certain degree of degradation over time.

Sol-gel coatings doped with NPs such as graphene sheets would not act well enough as corrosion inhibitors in the chosen synthesis conditions, but they seemed to promote the formation of calcium phosphates (maybe hydroxyapatite), thus improving the alloy biocompatibility.

Although more extensive research is still needed, these results are promising for the use of $\mathrm{Mg}-\mathrm{Al}$ alloys for its applications in the biomedical field.

Author Contributions: J.L.-S., A.S. and N.C. conceived the work and coordinated the research. L.R.A. prepared the samples and carried out the weathering experiment. J.L.-S., A.S., O.R.d.l.F. and N.C. carried out the structural characterization. J.C.G. was responsible of the funding acquisition. All authors wrote and revised the manuscript and extensively discussed the results and their interpretation. All authors have read and agreed to the published version of the manuscript.

Funding: The authors acknowledge the Spanish Ministry of Science and Innovation for financing the projects RTI2018-095856-B-C21 (AEI/FEDER; PIE: 2021-60-E-030, PIE: 2010-6-OE-013, and PID2019104717RB-I00). A.S. acknowledges the financial support from the Comunidad de Madrid for an "Atracción de Talento Investigador" contract (no. 2017-t2/IND5395).

Acknowledgments: The authors acknowledge the CNME Unit of the UCM for SEM measurements.

Conflicts of Interest: The authors declare that they have no known competing financial interests or personal relationships that could have appeared to influence the work reported in this paper.

\section{References}

1. Qiu, C.; Fones, A.; Hamilton, H.G.C.; Adkins, N.J.E.; Attallah, M. A new approach to develop palladium-modified Ti-based alloys for biomedical application. Mater. Des. 2016, 109, 98-111. [CrossRef]

2. Prasad, K.; Bazaka, O.; Chua, M.; Rochford, M.; Fedrick, L.; Spoor, J.; Symes, R.; Tieppo, M.; Collins, C.; Cao, A.; et al. Metallic biomaterials: Current challenges and opportunities. Materials 2017, 10, 884. [CrossRef] [PubMed] 
3. El Hadad, A.A.; García-Galván, F.R.; Mezour, M.A.; Hickman, G.J.; Soliman, I.E.; Jiménez-Morales, A.; Barranco, V.; Galván, J.C.; Perry, C.C. Organic-inorganic hybrid coatings containing phosphorus precursors prepared by sol-gel on Ti6Al4V alloy: Electrochemical and in-vitro biocompatibility evaluation. Prog. Org. Coat. 2020, 148, 105834. [CrossRef]

4. Wang, L.; Yu, H.; Wang, S.; Qiao, L.; Sun, D. In-situ XAFS and SERS study of self-healing of passive film on Ti in Hank's physiological solution. Appl. Surf. Sci. 2019, 496, 143657. [CrossRef]

5. García-Galván, F.R.; Fajardo, S.; Barranco, V.; Feliu, S., Jr. Experimental apparent stern-geary coefficients for AZ31B Mg alloy in physiological body fluids for accurate corrosion rate determination. Metals 2021, 11, 391. [CrossRef]

6. Sezer, N.; Evis, Z.; Kayhan, S.M.; Tahmasebifar, A.; Koç, M. Review of magnesium-based biomaterials and their applications. J. Magnes. Alloy. 2018, 6, 23-43. [CrossRef]

7. Sumayli, A. Recent trends on bioimplant materials: A review. Mater. Today Proc. 2021, 46, 2726-2731. [CrossRef]

8. Kumar, K.; Das, A.; Prasad, S.B. Recent developments in biodegradable magnesium matrix composites for orthopaedic applications: A review based on biodegradability, mechanical and biocompatibility perspective. Mater. Today Proc. 2021, 44, 2038-2042. [CrossRef]

9. Feliu Jr, S.; Samaniego, A.; Barranco, V.; El-Hadad, A.A.; Llorente, I.; Serra, C.; Galván, J.C. A study on the relationships between corrosion properties and chemistry of thermally oxidised surface films formed on polished commercial magnesium alloys AZ31 and AZ61. Appl. Surf. Sci. 2014, 295, 219-230. [CrossRef]

10. Pacha-Olivenza, M.A.; Galván, J.C.; Porro, J.A.; Lieblich, M.; Díaz, M.; Angulo, I.; Cordovilla, F.; García-Galván, F.R.; FernándezCalderón, M.C.; González-Martín, M.L.; et al. Efficacy of laser shock processing of biodegradable Mg and Mg-1Zn alloy on their in vitro corrosion and bacterial response. Surf. Coat. Technol. 2020, 384, 125320. [CrossRef]

11. Shchukin, D.G.; Zheludkevich, M.; Yasakau, K.; Lamaka, S.; Ferreira, M.G.S.; Möhwald, H. Layer-by-layer assembled nanocontainers for self-healing corrosion protection. Adv. Mater. 2006, 18, 1672-1678. [CrossRef]

12. Rivero, P.J.; Redin, D.M.; Rodríguez, R.J. Electrospinning: A powerful tool to improve the corrosion resistance of metallic surfaces using nanofibrous coating. Metals 2020, 10, 350. [CrossRef]

13. Kokub, T.; Kim, H.-M.; Kawashita, M. Novel bioactive materials with different mechanical properties. Biomaterials 2003, 24, 2161-2175. [CrossRef]

14. Podbielska, H.; Ulatowska-Jarza, A. Sol-gel technology for biomedical engineering. Bull. Pol. Acad. Sci. Tech. Sci. 2005, 53, 261-271.

15. Wang, D.; Bierwagen, G.P. Sol-gel coatings on metals for corrosion protection. Prog. Org. Coat. 2009, 64, 327-338. [CrossRef]

16. Carbonell, D.J.; García-Casas, A.; Izquierdo, J.; Souto, R.M.; Galván, J.G.; Jiménez-Morales, A. Scanning electrochemical microscopy characterization of sol-gel coatings applied on AA2024-T3 substrate for corrosion protection. Corros. Sci. 2016, 111, 625-636. [CrossRef]

17. Abuín, M.; Serrano, A.; Llopis, J.; García, M.A.; Carmona, N. Silica doped with lanthanum sol-gel thin films for corrosion protection. Thin Solid Films 2012, 520, 5267-5271. [CrossRef]

18. Barranco, V.; Carmona, N.; Galván, J.C.; Grobelny, M.; Kwiatkowski, L.; Villegas, M.A. Electrochemical study of tailored sol-gel thin films as pre-treatment prior to organic coating for AZ91 magnesium alloy. Prog. Org. Coat. 2010, 68, 347-355. [CrossRef]

19. Hernández, L.; Veleva, L.; García-Galván, F.R.; Galván, J.C. Effect of $\mathrm{ZrO}_{2}$ and L-Cys nanoparticles as dopants in sol-gel of mesoporous silica coating for corrosion protection of AZ61 magnesium alloy. Rev. De Metal. 2019, 55, e155. [CrossRef]

20. Upadhyay, V.; Bergseth, Z.; Kelly, B.; Battocchi, D. Silica-Based Sol-Gel Coating on Magnesium Alloy with Green Inhibitors. Coatings 2017, 7, 86. [CrossRef]

21. Twite, R.L.; Bierwagen, G.P. Review of alternatives to chromate for corrosion protection of aluminium aerospace alloys. Prog. Org. Coat. 1998, 33, 91-100. [CrossRef]

22. Jafarzadeh, S.; Claesson, P.M.; Sundell, P.-E.; Tyrode, E.; Pan, J. Active corrosion protection by conductive composites of polyaniline in a UV-cured polyester acrylate coating. Prog. Org. Coat. 2016, 90, 154-162. [CrossRef]

23. Bazlia, L.; Yusuf, M.; Farahani, A.; Kiamarzi, M.; Seyedhosseini, Z.; Nezhadmansari, M.; Aliasghari, M.; Iranpoor, M. Application of composite conducting polymers for improving the corrosion behavior of various substrates: A Review. J. Compos. Compd. 2020, 2, 228-240. [CrossRef]

24. Siva, T.; Ramadoss, A.; Sathiyanarayanan, S. Emerging Action of Corrosion Prevention Based on Sustained Self-healing Coatings Surf. Interfaces 2021, 26, 101440. [CrossRef]

25. Ashraf, M.A.; Liu, Z.; Peng, W.-X.; Yoysefi, N. Amino acid and $\mathrm{TiO}_{2}$ nanoparticles mixture inserted into sol-gel coatings: An efficient corrosion protection system for AZ91 magnesium alloy. Prog. Org. Coat. 2019, 136, 105296. [CrossRef]

26. Borisova, D.; Möhwald, H.; Shchukin, D.G. Mesoporous silica nanoparticles for active corrosion protection. ACS Nano 2011, 5 , 1939-1946. [CrossRef]

27. Liu, J.; Lou, Y.; Zhang, C.; Yin, S.; Li, H.; Sun, D.; Sun, X. Improved corrosion resistance and antibacterial properties of composite arch-wires by N-doped $\mathrm{TiO}_{2}$ coating. RSC Adv. 2017, 7, 43938-43949. [CrossRef]

28. Xiong, L.; Liu, J.; Li, Y.; Li, S.; Yu, M. Enhancing corrosion protection properties of sol-gel coating by pH-responsive amino-silane functionalized graphene oxide-mesoporous silica nanosheets. Prog. Org. Coat. 2019, 135, 228-239. [CrossRef]

29. Maeztu, J.D.; Rivero, P.J.; Berlanga, C.; Bastidas, D.M.; Palacio, J.F.; Rodríguez, R. Effect of Graphene oxide and fluorinated polymeric chains incorporated in a multilayered sol-gel nanocoating for the design of corrosion resistant and hydrophobic surfaces. Appl. Surf. Sci. 2017, 419, 138-149. [CrossRef] 
30. Matatagui, D.; López-Sánchez, J.; Peña, A.; Serrano, A.; del Campo, A.; de la Fuente, O.R.; Carmona, N.; Navarro, E.; Marín, P.; Horrillo, M.C. Ultrasensitive $\mathrm{NO}_{2}$ gas sensor with insignificant $\mathrm{NH}_{3}$-interference based on a few-layered mesoporous Graphene. Sens. Actuators B Chem. 2021, 335, 129657. [CrossRef]

31. Palanisamy, G. Corrosion Inhibitors; Ambrish, S., Ed.; IntechOpen: London, UK, 2019. [CrossRef]

32. Tkacz, J.; Sloukova, K.; Minda, J.; Drabikova, J.; Fintova, S.; Dolezal, P.; Wasserbauer, J. Influence of the composition of the Hank's Balanced Salt Solution on the corrosion Behavior of AZ31 and AZ61 Magnesium Alloys. Metals 2017, 7, 465. [CrossRef]

33. ASTM Standard G31-72; Standard Practice for Laboratory Immersion Corrosion Testing of Metals (Reapproved 1990); Annual Book of ASTM Standards. ASTM International: West Conshohocken, PA, USA, 2004; p. 302.

34. García, M.A.; Paje, S.; Llopis, J.; Villegas, M.A. Influencia de las condiciones de preparación en la luminiscencia de recubrimientos de sílice pura. Bol. De La Soc. Española De Artic. Cerámica Y Vidr. 2000, 39, 641-646. [CrossRef]

35. Samaniego, A.; Llorente, I.; Feliu, S. Combined effect of composition and surface condition on corrosion behaviour of magnesium alloys AZ31 and AZ61. Corros. Sci. 2013, 68, 66-71. [CrossRef]

36. Gong, H.; Wang, K.; Strich, R.; Zhou, J.G. In vitro biodegradation behavior, mechanical properties, and cytotoxicity of biodegradable $\mathrm{Zn}-\mathrm{Mg}$ alloy. J. Biomed. Mater. Res. B Appl. Biomater. 2015, 103, 1632-1640. [CrossRef] [PubMed]

37. El Hadad, A.A.; Peón, E.; García-Galván, F.R.; Barranco, V.; Parra, J.; Jiménez-Morales, A.; Galván, J.C. Biocompatibility and corrosion protection behaviour of hydroxyapatite sol-gel-derived coatings on Ti6Al4V alloy. Materials 2017, 10, 94. [CrossRef] [PubMed] 